\title{
Organization a Culture of Self-Education of Music Teachers
}

\author{
Elena Aleksandrovna Dyganova ${ }^{1} \&$ Ziliya Mukhtarovna Yavgildina ${ }^{1}$ \\ ${ }^{1}$ Kazan (Volga region) Federal University, Russian Federation \\ Correspondence: Elena Aleksandrovna Dyganova, Kazan (Volga region) Federal University, Kremlevskaya St., \\ 18, Kazan 420008, Russian Federation.
}

Received: January 5, 2015 Accepted: February 22, 2015 Online Published: May 28, 2015

doi:10.5539/ies.v8n6p95

URL: http://dx.doi.org/10.5539/ies.v8n6p95

\begin{abstract}
The article discusses the culture of self-education of music teacher as a professionally necessary quality of a modern specialist in the field of music education. The author proposes finalized definitions of basic concepts; consistently reveals the essence, structure, criteria and indicators of self-culture of music teacher; reveals the potential of conducting and choral disciplines as pedagogical tool. As the mechanism of formation of pedagogical culture of self-education of the future music teacher the author's model is suggested. The results of its experimental testing in terms of educational practice prove the effectiveness of the study.
\end{abstract}

Keywords: self-education, music-pedagogical self-education, culture of self-education, conducting and choral disciplines, pedagogic model, future music teacher

\section{Introduction}

Priority area of educational policy in Russia is a complex modernization of education at all levels and stages. In this context, particular important is the formation of musical teaching corps, corresponding to the needs of modern life. Trained professionals are called to be the bearers of ideas updates based on conservation and enhancement of the best traditions of Russian musical teacher education. Requirements for the level of education of the music teacher are high enough: the future professional should have a certain amount of knowledge, skills, possess a synthesis of common cultural, professional and specialized competencies to carry out professional self-education and personal growth, to design further educational path and professional career.

The problem of self-identity is the subject of study of various fields of science. In particular, the psychological basis of self-education are studied (Zimniayia, 2001; Rubinstein, 2002); philosophical and methodological aspects of self-education in its relation to self-discipline and self-development are discussed (Andreev, 2005; Osipov \& Prygin 2012). Pedagogical science revealed the essence of self-education students, methods and forms of its development (Buriak, 2007; Morozova, 2010; Georgii-Hemming \& Westvall, 2010; Stalhammar, 2006); summarizes the ways of forming pupil need in self-education (Borisov, 2009; Yudenko, 2007; Honig, 2006); studied some aspects of self-education of university students (Ganin, 2004; Glukhova, 2010); the problems of development of pedagogical self-education are discussed (Ganchenko, 2004); the problems of self-education of students are considered (Oparin, 2002; Preobrajenskayia, 2008; Fominf, 2007).

Problems of development and improvement of musical and pedagogical self-education with the specific of art didactics are reflected in scientific works (Abdullin et al., 2002; Shkolyar et al., 2001). Works (Aliev et al., 2001; Fungal, 2010; Wright, 2008; Oliveira, 2005; Powell, 2014) devoted to the formation of professional culture of the music teacher.

Despite the fact that the problem of self-education is the focus of modern pedagogy, a special study on a culture of self-education of the future music teacher in the course of development of the conducting and choral disciplines, has not yet been carried out. In this context, the relevance of the development of the mechanisms of formation of pedagogical culture of self-education of the future music teacher by means of conducting and choral disciplines in higher education system is not in doubt.

\section{Method}

The methodological basis of research on the scientific level the systemic and holistic approach is identified provided the opportunity to explore areas such as education and culture. In accordance with the logic of research for the task in the experimental work the following methods were used: 
a) Theoretical methods-steps: identification and resolution of conflicts, statement of the problem, the construction of hypotheses of the study, the construction of phases, stages and phases of research, inductive-deductive method of proof; methods of operations: analysis, synthesis, comparison, abstraction, specification, synthesis, simulation allows to master the psychological and pedagogical, musical and pedagogical work on the problem under study.

b) Empirical methods-steps: site survey, monitoring, study and generalization of experience, experimental work, pedagogical experiment; methods of operations: questioning, testing, teacher observation, conversation, method of expert evaluations, and the mathematical treatment of the results of the study.

To test the efficiency of the developed pedagogical maintenance of the process of building a culture of self-education of the future music teacher by means of conducting and choral disciplines used a set of specially designed diagnostic methods (see. Table 1), aimed to assess the level of development of a culture of self-education for each component.

Table 1. Diagnostic tools

\begin{tabular}{ll}
\hline Components & Method \\
\hline 1. Questionnaire "Having the motivation to self-education activity" (Andreev, 2005). \\
2. Pedagogical supervision in the process of teaching and professional activities of the \\
student-musician on the control events, concert performances, scientific events. \\
3. Conversations with students. \\
1. Research creative task "written annotation on the choral work" according to the plan \\
and requirements for registration "(Dyganova \& Yavgildina, 2014). \\
2. Case study "Rehearsal work with choral work" (Dyganova \& Yavgildina, 2014). \\
3. Pedagogical supervision in the process of teaching and professional activities of the \\
student-musician on the control events, concert performances, scientific events. \\
1. Questionnaire "My self-regulation of behavior - SSP 98" (Morosanova \& Konoz, \\
2000). \\
2. Creative task "concert performance of choral works" (Dyganova \& Yavgildina, \\
2014). \\
3. Pedagogical supervision in the process of teaching and professional activities of the \\
student-musician on the control events, concert performances, scientific events.
\end{tabular}

\section{Main Part}

In order to reveal the essence of the main concepts of the culture of self-education of music teacher was conducted consistent study of conjugate concepts: "self-education", "pedagogical self-education", "self-education of music teacher", "culture" and "pedagogical culture". The results of the analysis, comparison and synthesis enabled the authors to formulate a definition of the basic concepts of "culture of self-education of music teacher" - a phenomenon of relation system of professional education and personality of the music teacher, suggesting a high level of scientific organization of intellectual and creative work, achieved through musical and pedagogical self-education. In turn, the "musical pedagogical self-education", is considered by us as an independent systematic, purposeful cognitive activity of the music teacher (music students) in the field of pedagogy and music formed on the basis of motives and voluntary intentions, promoting the development of the individual, exercised in the workplace (educational) and free (extracurricular) time.

On the basis of summarizing the results of the work, the structure of a culture of self-education of music teacher was determined, consisting of three interrelated components: value-motivational (pedagogical system of values, personal meanings, motives, interests, needs of a specialist, which forms the personality-value attitude of the teacher and musician promotes the development of musical and pedagogical self); cognitive-operational (basic culture of the person; a sufficient number of professional and special knowledge and skills to apply them, the ability to choose sources of knowledge and forms of self-education activities, additional knowledge of musical and pedagogical sciences, obtained mainly in self-education activity); reflexive control (self-regulation system of self-identity of his professional activities, which are present in the composition of reflexive control operation: 
self-observation, self-awareness, self-esteem, self-correction, self-control).

To determine the status of the problem in the practice of higher education and to identify the state of the forming culture of music teachers and students, a study was conducted, the results of which are shown in Table 2.

Table 2. Levels of formation of self-culture of music teacher on the ascertaining stage

\begin{tabular}{|c|c|c|c|c|c|c|}
\hline \multirow{2}{*}{$\begin{array}{l}\text { Levels of culture of the } \\
\text { self-education }\end{array}$} & \multicolumn{2}{|c|}{$\begin{array}{l}\text { Graduates of colleges of musical and } \\
\text { ped. profile } 204 \text { pers. }(51.5 \%)\end{array}$} & \multicolumn{2}{|c|}{$\begin{array}{l}\text { Music School Graduates and school } \\
\text { of Arts } 192 \text { pers. }(48.5 \%)\end{array}$} & \multicolumn{2}{|c|}{ Total 396 pers. $(100 \%)$} \\
\hline & $\begin{array}{c}\text { Number of } \\
\text { students (pers.) }\end{array}$ & $\begin{array}{l}\text { Number of } \\
\text { students (\%) }\end{array}$ & $\begin{array}{c}\text { Number of } \\
\text { students (pers.) }\end{array}$ & $\begin{array}{l}\text { Number of } \\
\text { students (\%) }\end{array}$ & $\begin{array}{c}\text { Number of } \\
\text { students (pers.) }\end{array}$ & $\begin{array}{l}\text { Number of } \\
\text { students }(\%)\end{array}$ \\
\hline Low & 147 & 37.1 & 165 & 41.7 & 312 & 78.8 \\
\hline Average & 39 & 9.9 & 21 & 5.3 & 60 & 15.2 \\
\hline High & 18 & 4.5 & 6 & 1.5 & 24 & 6 \\
\hline
\end{tabular}

The results of this stage of the experiment demonstrated the prevalence of low levels of formation of a culture of self-education of music teacher in the surveyed students, which confirmed the need to develop a pedagogical model of organizing the process of creating a culture of self-education of student musician. The authors of this study believe that the most effective means may make the conducting and choral discipline.

Expediency to identify pedagogical potential of conducting and choral disciplines in building a culture of self-education of the future music teacher is proven by the results of a comparative analysis of the professional activities of a music teacher and choir of the coincidence of all positions (Dyganova, 2011).

Based on the pedagogical views of the leading conductors and educators, we found three approaches to determining the content of choral conducting: 1) as an activity that exists for deshifrovki-"decoding" the musical interaction and poetic texts and their translation in sign language; 2) as a kind of choral collective management; 3 ) as a kind of musical performance. In the professional development all three positions are in close interaction, and each of them is the relevant section in the process of training music teacher.

In the process of analyzing the content of disciplines of choir conductor loop ("choral classes and practical work with the choir", "choral conducting and choral reading scores," "horovedeniye", "History and Theory of Choral Music" et al.) the following conclusions were obtained:

- Work programs of disciplines of choir conductor loop composed in reliance on classically trained choir conductor;

- Obligatory section in the maintenance of discipline is vocal and choral work in secondary school;

- Conducting and choral preparation of the future music teacher is performed using complex interdisciplinary connections.

Form of training on conducting and choral disciplines have a wide range of lectures, workshops, seminars, private lessons, classroom and extracurricular forms of independent work of students. Each classroom and extracurricular forms of organization of learning at a certain stage of professional development of the student-musician has its own advantages, so the efficiency is achieved when the alternation of different forms of training or complex application. Special role in the process of preparation of the future music teacher is performed by choral workshops aimed at the use of the experience of self-activity in the real world.

During the development of the conducting and choral disciplines self-educational activity of the student is one of the leading types of learning and cognitive activity, due to the phased pre-treatment to the main result-public performance of choral works. In addition, the modern requirements for the educational process in high school orient students to the systematic teaching and research work in the form of reports and participation in scientific conferences of different status (faculty, university, national, international); publications in scientific books and journals; participation in special competitions, thematic concerts, musical and educational lecture halls and festivals.

Based on the study of the extensive list of works on conducting and choral art, summarizing the experience of their own teaching activities opportunities of choir conductor disciplines for the organization of independent work of students were uncovered, including: 
- Features of pre choral conducting training of the future music teacher, which is carried out in isolation from the "tool-choir";

- Integration communication of choir conductor loop disciplines;

- A wide range of curricular and extracurricular forms of organization conducting and choral education student musician;

- To exercise multifunctional educational and professional activities of the student;

- A major share of students' independent work, contribute to the formation of self-experience of student musician.

Implementation of the pedagogical potential of conducting and choral disciplines required the development of a pedagogical model of building a culture of self-education of student musicians which included the following structural and functional components: target, methodological, substantive and procedural, diagnostic and performance.

In the target component of self-education of the future music teacher culture acts as the final landmark. Methodological component comprises a plurality of methodological approaches and pedagogical principles, based on which the study was conducted. By the fundamental approach we defined competence as a system integrator, holistic, knowledge-oriented, student-activity and cultural approach that focuses on a new vision of the objectives and evaluation of vocational education and the inclusion of students-musicians in different activities. Implementation of approaches carried out in reliance on the totality of the following learning principles: systematic, scientific, focus the learning process on the overall development of the student's personality, consciousness and self-reliance.

Content-processing component includes:

- The content of the conducting and choral disciplines, structured into five didactic units (theoretical, technological, research, performing, teaching);

- Methods of stimulation, motivation and self-motivation doctrine, organization, and self-organization, self-control and the efficiency of learning and cognitive activity;

- Forms of work (classroom lectures, practical classes, seminars, workshops, private lessons, independent work of students, extracurricular: independent work of students, preparation of reports and participation in scientific conferences, publications in scientific books and journals, participate in special competitions, thematic concerts, musical and educational lecture halls and festivals, systematic visits to concerts, theater performances, museums, exhibitions, lectures, workshops, etc.);

- Teaching means(traditional: books, music books and teaching aids, visual aids training and demonstration devices, technical means of teaching, etc; special: author's pedagogical work in print and electronic format, distance learning course "History and Theory of choral performing "learning management system MOODLE (Modular Object-Oriented Dinamic Learning Environment).

Diagnostic-effective component is the definition of performance of models of building a culture of self-education of the future music teacher in the implementation of the pedagogical potential of conducting and choral disciplines. Based on the structural components of the culture of self-education of music teacher, serving as criteria for its formation, analysis of pedagogical potential of conducting and choral disciplines have developed indicators for each component-test on three levels of formation of the culture of self-education of music teacher.

Indicators of high level of culture of self-education of music teacher on components criteria are following: value-motivational component-setting self on the link with personal and professional interests; motivated focus on self-development and the development of innovative practices in pedagogy of music education; understanding of the necessity of ownership methods of scientific knowledge; desire to take place in the profession and to gain credibility; cognitive-operating-comprehensive knowledge on conducting and choral disciplines in unity with the conscious intersubject communications; free use of skills of self-activity: goal setting, working with sources of information, evaluation of information material, processing of the results; possession of mental operations (analysis, synthesis, comparison, dismemberment, generalization, classification, etc.); ability to interpret choral work based on a comprehensive analysis; application of basic and advanced knowledge on the methodology of the work with the choir; possession of skills rehearsal work; control and reflective-the presence of conscious goals, ideals, meanings and aspirations of the individual teacher-musician; possession of personal and professional skills of self-analysis, self-esteem level of self-education activities in the field of music pedagogy 
and performing; possession of self-control and self-regulation mechanisms of self-activity.

Indicators of medium level of culture of self-education of music teacher: value-motivational component-self-understanding of the relationship with personal and professional interests; intermittent need for self-development and assimilation of innovative experiences in music pedagogy; lack of understanding of the need for ownership of the methods of scientific knowledge; lack of the need to establish as a musician and to gain credibility. Cognitive-operational - basic knowledge of conducting and choral disciplines, coupled with the unconscious intersubject communications; difficulties in use skills of self-activity: goal setting, working with sources of information, evaluation of information material, processing of the results; partial use of mental operations (analysis, synthesis, comparison, dismemberment, generalization, classification, and so on.); not pronounced interpretation ability of choral works based on a comprehensive analysis; use of basic knowledge of the methodology of the work with the choir; not pronounced possession of rehearsal work skills; control-reflective-understanding of the goals, ideals, meanings, aspirations required for personality of the music teacher; partial grasp of personal and professional skills of self-analysis, self-esteem level of self-education activities in the field of music pedagogy and performing; episodic manifestation of self-possession and self-regulation mechanisms of self-activity.

Indicators of low culture of self-teacher-musician: value-motivational component-the lack of understanding of the relationship of self to the personal and professional interests; lack of desire for self-development and development of innovative experiences in music pedagogy; lack of understanding of the need for ownership of the methods of scientific knowledge; weakly expressed a desire to take place in the profession and to gain credibility; cognitive-operational-basic knowledge of conducting and choral disciplines are isolated character; lack of skills of self-activity: goal setting, working with sources of information, evaluation of information material, processing of the results; weakly expressed possession of mental operations (analysis, synthesis, comparison, dismemberment, generalization, classification, etc.); lack of ability to interpret the choral work based on a comprehensive analysis; occasional use of basic knowledge of the methodology of the work with the choir; weakly expressed possession of skills rehearsal work; control and reflective - lack of understanding of the goals, ideals, meanings, aspirations and personality required teacher-musician; weakly expressed possession of personal and professional skills of self-analysis, self-esteem level of self-education activities in the field of music pedagogy and performing; lack of knowledge of the mechanisms of self-control and self-regulation of self-activity.

We developed a pedagogical model for the formation of self-education culture of the future teacher-musician means of conducting and choral disciplines, we were subjected to evaluation by the author's classification (Selevko, 2005), the results presented in Table 3.

Table 3. Classification of characteristic of pattern formation culture of self-education of future the music teacher

\begin{tabular}{|c|c|c|}
\hline $\begin{array}{c}\# \\
\text { Number }\end{array}$ & $\begin{array}{l}\text { Classification characteristics (by G. K. } \\
\text { Selevko) }\end{array}$ & Characteristic of the model \\
\hline 1 & On application level & complex-subjectective \\
\hline 2 & on the philosophical basis & humanistic \\
\hline 3 & on the main methodological approach & systematic, person-oriented, complex, integrated \\
\hline 4 & by factor of development & sociogenic, psychogenic \\
\hline 5 & $\begin{array}{l}\text { on the scientific concept (mechanism) } \\
\text { of transfer and development of } \\
\text { experience }\end{array}$ & $\begin{array}{l}\text { associative-reflexive, developing training and education, } \\
\text { cognitive, activity }\end{array}$ \\
\hline 6 & $\begin{array}{l}\text { to focus on the personal sphere and } \\
\text { the core competencies of the } \\
\text { individual }\end{array}$ & $\begin{array}{l}\text { informational, operational, aimed at self-development } \\
\text { (self-governing mechanisms of personality), effective } \\
\text { practical and creative }\end{array}$ \\
\hline 7 & the nature of the content and structure & $\begin{array}{l}\text { professionally oriented, general culture, specific subject, } \\
\text { aesthetic, complex }\end{array}$ \\
\hline 8 & $\begin{array}{l}\text { by the form of social and educational } \\
\text { activities }\end{array}$ & training, mentoring, developing \\
\hline
\end{tabular}


$9 \quad$ by type of management of training and educational and social process

10 at prevailing (dominant) methods and techniques of training

11 on organizational forms

12 on the prevalence of learning tools on approach to training and orientation of pedagogical interaction in the direction of modernization and 14 relation to the traditional educational system classic, software, based on self-study data, using a system of "consultant", self-regulatory

search, research, dialogic, active, developing

individual, collective, self-study

verbal, symbolic, visual, associative, programming, practical

democratic, promoting of self-education organization

based on the increase and intensify the self-educational activity

aimed at professional education, where students from teacher training University are the music teachers in future.

Experimental study was conducted at the Graduate School of Arts named after Salih Saidashev from Kazan (Volga) Federal University, Kazan State University of Culture and Arts with the participation of 396 students in 2008-2011.

On the forming stage equal to its initial level control (CG) and experimental (EG) group were formed . To determine the initial level of formation of self-culture of the future music teacher in the course of development of the conducting and choral disciplines students from CG (48 students) and EG (47 students) were used questionnaires, practical and written research assignments.

At the initial stage of forming experiment $63.1 \%$ of students from CG and $65.3 \%$ of EG students had low self-education culture; $26.5 \%$ of CG students and $27 \%$ of EG students were average; $10.4 \%$ of students in the CG and $7.7 \%$ of EG students showed a high level.

The purpose of the formative experiment was to increase the level of self-education culture 0f music teacher on all counts of the three components, which is aimed at achieving the following objectives: 1) implementation of the model of building a culture of self-education of the future music teacher in the course of development of the conducting and choral disciplines; 2) use of copyright in the educational process of educational development to effectively organize students' self-education.

Building a culture of self-education with students-musicians in EG were phased in educational and pedagogical interaction where there is a stimulation of independent cognitive activity of students-musicians in all activities. At the initial stage route of individual self-education was planned. Planning of self-activity of the student musician allowed organizing systematic work on the formation and regulation of the relationship of self and professional experience. Independent work of students from EG for the development of choir conductor repertoire performed mainly in research and creative activity, thus establishing a stable motivation to the process of self-education, to equip the future music teacher with self-technologies, to establish an adequate professional self-estimation.

For the formation of self-experience activity every student from EG have been proposed various types and forms of self-education, such as the selection of song and choral repertoire, preparation of research reports and presentations at seminars and conferences, written annotations on vocal and choral works, preparation of reports, term papers and their protection, the preparation of scientific publications.

Students from EG had as special learning tools developed by us methodological support in the form of teaching aids "Self preparing music students for practical work with the choir", "Sabantuy. Concert repertoire of youth choirs "and guidelines "Independent on the implementation of the annotations on the vocal and choral works "in print and electronic format, allowing to organize independent work on the development of disciplines of choir conductor loop. Given the current potential of information technology and e-learning, for the organization of self-work of students in the discipline "History and Theory of Choral Music" and-course learning management system MOODLE.

During the formative experiment EG students were active participants in festivals and competitions in various formats, allow to discover maximum intellectual and creative resources of the student musician; to hone the 
necessary qualities such as desire and achieve the goal, hard work, discipline, the will, the development of different faces talent, adapting to the situation, to overcome the fear of public stage, formed the experience of self-regulation.

In operation, the model of building a culture of self-education of students from EG systematic and balanced mastered all five areas of choral conducting training: theoretical, technological, research, performance, and teacher.

On the control stage of the pilot study was conducted repeat diagnostics of formation of culture of self-education culture of music teacher with students from CG and EG, the results are shown in Tables 4 and 5.

Table 4. Levels of formation of self-education culture of students from the control group at the control stage

\begin{tabular}{lllll}
\hline \multirow{2}{*}{ Levels } & \multicolumn{2}{l}{ Initial results } & \multicolumn{2}{l}{ Final results } \\
\cline { 2 - 5 } & CG (48 pers.) & \multicolumn{2}{l}{ CG (48 pers.) } \\
\cline { 2 - 5 } & pers. & $\%$ & pers. & $\%$ \\
\hline High & 5 & 10.4 & 7 & 14.6 \\
Average & 13 & 26,5 & 17 & 35.4 \\
Low & 30 & 63.1 & 24 & 50 \\
\hline
\end{tabular}

Table 5. Levels of formation of self-education culture of students from the experimental group at the control stage

\begin{tabular}{lllll}
\hline \multirow{2}{*}{ Levels } & \multicolumn{2}{l}{ initial results } & \multicolumn{2}{l}{ final results } \\
\cline { 2 - 5 } & EG (47 pers.) & \multicolumn{2}{l}{ EG (47 pers.) } \\
\cline { 2 - 5 } & pers. & $\%$ & pers. & $\%$ \\
\hline High & 3 & 7.7 & 11 & 23.4 \\
Average & 13 & 27 & 23 & 49 \\
Low & 31 & 65.3 & 13 & 27.6 \\
\hline
\end{tabular}

Comparative analysis of the data showed a significant increase in the level of culture of self-education of the music teacher in the EG, while in the CG has not undergone significant changes that proves the effectiveness of the implementation of the author's model of building a culture of self-education of music teacher in the course of development of the conducting and choral disciplines.

\section{Discussing and Results}

1) A definition of the concepts of "culture of self-education of music teacher" as a phenomenon of relations of professional education and personality of the music teacher, suggesting a high level of scientific organization of intellectual and creative work, achieved through musical and pedagogical self-education; "Musically-pedagogical self-education"-an independent systematic, purposeful cognitive activity of the music teacher (student musicians) in the field of pedagogy and music formed on the basis of motives and voluntary intentions, promoting the development of the individual, exercised in the workplace (training) and free (extracurricular) time.

2) The structure of a culture of self-education of music teacher composed of interrelated components: value-motivational, cognitive-operational and control reflexive and content of each component.

3) Pedagogical potential of conducting and choral disciplines comprising the features of the pre-choral conducting training of the future music teacher was identified, which is carried out in isolation from the "tool-choir"; integration communication disciplines choir conductor loop; a wide range of curricular and extracurricular forms of organization conducting and choral education of music teacher; opportunity to carry out multifunctional educational and professional activities of the student; the predominant share of independent work of students, contributing to the formation of self-experience of the music teacher.

4) Developed, theoretically proved and implemented in the educational process of author's model of building a 
culture of self-education of music teacher with means of conducting and choral disciplines, suggest the following interrelated components: target (target); methodological (a set of methodological approaches and principles); meaningful Procedure (content, methods, forms of work, resources); diagnostic and performance (structural components of the culture of self-education of music teacher, teacher diagnosis, levels of formation of a culture of self-education of teacher, musician and performance).

5) The classification characteristic model of building a culture of self-education of the future music teacher to 15 parameters, were carried out.

6) The criterion base was established from which to explore the effectiveness of a pedagogical model developed by creating a culture of self-education of music teacher in the course of development of the conducting and choral disciplines.

7) The author's teaching kit in the form of printed and electronic teaching aids was developed and implemented, distance course learning by management system MOODLE, aimed at providing a system of self-organization of students.

\section{Conclusions}

1) Specification of the essence of the basic concepts of the study "culture of self-education of music teacher" and "musical-pedagogical self-education".

2) We propose a three-component structure of the culture of self-education of music teacher, specify the content of each component.

3) Pedagogical possibilities conducting and choral disciplines in building a culture of self-education of music teacher were revealed.

4) The effectiveness of educational practices implemented in the author's model of building a culture of self-education of the future music teacher were proven with means of conducting and choral disciplines, allowing to optimize the training of the future music teacher and contributes to raising the cultural level of self-education of music teacher.

Formulated by the authors scientific findings expand scientific understanding of the training of music teachers in high school and can be used in future studies in the area of professional development and personal development of the music teacher.

\section{Acknowledgements}

The work is performed according to the Russian Government Program of Competitive Growth of Kazan Federal University.

\section{References}

Abdullin, E. B., Vanilihina, O. V., \& Morozova, N. V. (2002). Methodological culture of the teacher-musician studies. Guide for students. Executive. ped. Proc. institutions. Moscow: Publishing Center "Academy”.

Aliyev, Y. B., Genik, E. A., \& Erganzhieva, L. N. (2001). Steps pedagogical creativity: Scientific Resource Kit for teachers. Moscow: Russian Academy of Education. Institute of Education theory and pedagogy.

Andreev, V. I. (2005). Pedagogy of higher education. Innovative-prognostic course: textbook. Kazan: Innovation Center.

Borisova, E. A. (2009). Formation of readiness of students to educate themselves as a pedagogical problem. Proceedings of the Samara Scientific Center of the Russian Academy of Sciences, 4(2), 318-322.

Buriak, V. K. (2007). Activity and independence of students in cognitive activities. Pedagogy, 8, 71-78.

Dyganova, E. A. (2011). Formation of self-competence of the future teacher of music in the process of mastering the conducting and choral disciplines. Education and self-development, 4(26), 17-22.

Dyganova, E. A., \& Yavgildina, Z. M. (2014). Building a culture of self-education of the future music teacher: A monograph. Kazan: IFMK CFI.

Fomina, E. N. (2007). Formation of self-educational competence of students through the use of modular technology (for example, secondary vocational schools) ( $\mathrm{PhD}$ thesis, Astrakhan State University. Astrakhan, Russia).

Ganchenko, I. O. (2004). Development of the personality of the teacher in the system of continuous professional self ( $\mathrm{PhD}$ thesis, Krasnodar Academy of the Russian Interior Ministry. Krasnodar, Russia). 
Ganin, E. A. (2004). Modern information and communication technologies as a means of self-education of future teachers to educate themselves (Dissertation of the candidate of science, Transbaikal State Pedagogical University. NG Chernyshevsky. Chita, Russia).

Georgii-Hemming, E., \& Westvall, M. (2010). Music education-A personal matter? Examining the current discourses of music education in Sweden. British Journal of Music Education, 27(1), 21-33. http://dx.doi.org/10.1017/S0265051709990179

Glukhova, E. A. (2010). Interdisciplinary communication as a means of self-education students in high school ( $\mathrm{PhD}$ thesis, Chelyabinsk State Pedagogical University, Chelyabinsk, Russia).

Gribkova, O. V. (2010). Theory and practice of formation of professional culture of the teacher-musician (PhD thesis, Moscow City Pedagogical University, Moscow, Russia).

Honig, M. (2006). New Directions in Education Policy Implementation. Albany: State University of New York Press.

Morosanova, V. I., \& Konoz, E. M. (2000). Stylistic self-regulation of human behavior. Questions of psychology, 2, 118-127.

Morozova, V. V. (2010). Formation of self-educational competence of students as a condition of education in the form of external (PhD thesis, State University of Russia, Kant, Kaliningrad, Russia).

Oliveira, A. (2005). Music teaching as culture: Introducing the pontes approach. International Journal of Music Education, 23(3), 205-216. http://dx.doi.org/10.1177/0255761405058233

Oparin, U. G. (2002). Organizational-pedagogical conditions of self-education of university students ( $\mathrm{PhD}$ thesis, Nizhny Novgorod State Linguistic University name after N.A. Dobrolyubov, Nizhny Novgorod, Russia).

Osipov, P. N., \& Prygin, G. S. (2012). Features of the structure of professional consciousness of students with different levels of development of an effective autonomy. Bulletin of Kazan Technological University, 15(B.16), 300-304.

Powell, S. R. (2014). Examining preservice music teacher concerns in peer- and field-teaching settings. Journal of Research in Music Education, 61(4), 361-378.

Preobrajenskayia, I. N. (2008). Formation of self-educational competence of students of art-graphic specialties: On a material of disciplines of the information loop ( $\mathrm{PhD}$ thesis, Voronezhsky State Pedagogical University, Voronezh, Russia).

Rubinstein, S. L. (2002). Fundamentals of General Psychology. St. Petersburg: St. Petersburg.

Scholar, L. V., Scholar, V. A., \& Kritskaya, E. D. (2001). Music education in schools: Proc. Guide for students. muses factor and Dep. Executive and environments ped. Proc. institutions. Moscow: Publishing Center "Academy".

Selevko, G. K. (2005). Educational technology based on didactic and methodological improvements OHR. Moscow: SRI school technology.

Stalhammar, B. (2006). Musical Identities and Music Education. Aachen: Shaker

Wright, R. (2008). Thinking Globally, Acting Locally: Informal Learning and Social Justice in Music Education. Music Education as Liberatory Education. Paper presented at the International Society of Music Education, World Conference, Bologna, 20-25 July 2008.

Yudenko, T. A. (2007). Self-education students in domestic pedagogics of second half of XX century: Continuity and innovation ( $\mathrm{PhD}$ thesis, Pyatigorsk State Linguistic University, Pyatigorsk, Russia).

Zimniayia, I. A. (2001). Educational psychology: A textbook for high schools. Moscow: Logos.

\section{Copyrights}

Copyright for this article is retained by the author(s), with first publication rights granted to the journal.

This is an open-access article distributed under the terms and conditions of the Creative Commons Attribution license (http://creativecommons.org/licenses/by/3.0/). 